\title{
Towards a New Waste Regime?
}

Critical Reflections on China's Shifting Market for High-Tech Discards

Yvan Schulz

\section{OpenEdition \\ Journals}

\section{Electronic version}

URL: http://journals.openedition.org/chinaperspectives/6798

DOI: 10.4000/chinaperspectives.6798

ISSN: 1996-4617

\section{Publisher}

Centre d'étude français sur la Chine contemporaine

\section{Printed version}

Date of publication: 1 September 2015

Number of pages: $43-50$

ISSN: 2070-3449

Electronic reference

Yvan Schulz, "Towards a New Waste Regime? », China Perspectives [Online], 2015/3 | 2015, Online since 01 January 2017, connection on 28 October 2019. URL : http://journals.openedition.org/ chinaperspectives/6798; DOI : 10.4000/chinaperspectives.6798 


\title{
Towards a New Waste Regime?
}

\author{
Critical Reflections on China's Shifting Market for High-Tech Discards
}

YVAN SCHULZ

\begin{abstract}
This article explores how a multitude of entities vie for control over discarded electrical and electronic appliances in China. It analyses the strategies they deploy in order to gain or keep a competitive edge. Central government agencies, scientific research institutes, and large recycling groups, in particular, have recently joined forces with a view to redirecting flows of valuable consumer goods away from the so-called "informal" sector of the economy, notably by creating high barriers to entry. They strive to distinguish themselves from small-scale recyclers by making ample use of green propaganda and narratives of technological progress. However, China's state-sanctioned "management system" for "e-waste" recycling is not nearly as environmentally friendly as its proponents claim. It promotes a waste regime centred on "resources" - not products - and thereby contributes to accelerating and extending material cycles. Fully understanding its nature and impact requires seeing the link to other national policies, especially those promoting growth.
\end{abstract}

KEYWORDS: electrical and electronic appliances, recycling, environmental impact, waste regime, ecological modernisation.

$\mathrm{n}$ the People's Republic of China, much like in the rest of the world, consumption rates for electrical and electronic appliances (hereinafter e-appliances, i.e. television sets, computers, mobile phones, refrigerators, air-conditioners, etc.) have soared in recent decades, and the trend shows no signs of weakening. (1) Due to their rapid obsolescence, these consumer goods are also discarded in ever greater numbers. ${ }^{(2)}$ What becomes of them is therefore a matter of concern, especially for the environment. But the question of how to deal with these objects is a complex one, for several reasons. First, they form a heterogeneous category, which includes a multitude of devices, components, and materials, the properties of which vary greatly. Some of them are technologically elaborate or require a wealth of resources to make, transform, or unmake, while others are relatively simple. Some fetch high prices and have dedicated global markets, whereas others lack any commercial value. Some contain toxic substances that, if released, can damage the environment and human health. Others, by contrast, are rather harmless.

Second, the design and adoption of an official system for dealing with discarded e-appliances is a highly political issue. The validation by state authorities of certain technologies and business models as appropriate, and the parallel condemnation of others, reveals a particular conception of what these objects are and where their value lies. It also implies a decision about to whom they should be entrusted and for what purpose. The parameters of a given "waste regime," a concept I borrow from Zsusza Gille, ${ }^{(3)}$ result from power struggles and have far-reaching consequences. They guide material and financial flows into new directions, make certain social actors more legitimate than others - thus allowing them to play a predominant role - and affect the quality of the environment.

In China, the market for used e-appliances has undergone important changes in recent years. Small but well-networked economic actors, who used to have a collective monopoly on the trade and transformation of these commodities, are now starting to face competition from big industrial groups backed by the central government, academia, and the media as well as international and non-governmental organisations. The latter coalition ${ }^{(4)}$ has framed the issue as an environmental one by insisting on the pollution caused by small-scale recycling workshops and claims that the establishment of a state-sanctioned system would put an end to this.

Against this assumption, which has now become commonplace, I argue in this article that genuine concern for the environment plays only a secondary role in the central government's endorsement of a recycling system centred on material recovery and tailor-made for large industrial groups. Rather, this evolution is to be understood in terms of the dynamics of competition between those who control the trade at present and those who seek to control it in the future.

This claim is based on several insights, two of which need to be highlighted up front. First, China's state-led "system for the management of waste electrical and electronic equipment (WEEE)" (dianzi dianqi feiqiwu guanli zhidu 电子电器废弃物管理制度) is not nearly as green as its proponents would have people believe. The so-called "formal" (zhenggui 正规) and "informal" (fei zhenggui 非正规) sectors of the economy ${ }^{(5)}$ are often juxtaposed when it comes to judging environmental performance, and in the vast majority of cases, the comparison is based on one sole criterion, namely the impact of dismantling and processing activities. This is supposed to - and generally does - make big recycling plants seem cleaner and more efficient than small recycling workshops. To be fair, however, one should also take into account at least two additional factors:

Acknowledgements: This research was funded by the Swiss National Science Foundation (project number 100013_149559). A first version of the paper was presented at the French Centre for Research on Contemporary China (CEFC)'s New European Research on Contemporary China Conference (Beijing, July 2014). Among the people who read subsequent drafts, Josh Goldstein, Ellen Hertz, Ole J. Kaland, Benjamin Steuer, Thierry Theurillat, and Amy Zhang deserve special thanks.

1. Feng Wang et al., E-Waste in China: A Country Report, Bonn, United Nations University, 2013, p. 10.

2. According to the United Nations University, China had the largest amount of discarded appliances "on the market" in 2012, namely 11 million metric tons. See http://step-initiative.org/ index.php/Overview_China.html (accessed in January 2015).

3. Zsuzsa Gille, "Actor Networks, Modes of Production, and Waste Regimes: Reassembling the MacroSocial," Environment and Planning A, Vol. 42, No. 5, 2010, pp. 1049-1064.

4. These actors participate in the same conferences, social media networks, and partnership programs.

5. For a compelling critique of this dichotomy, see Bruno Lautier, L'Economie informelle dans le Tiers-monde (Informal economy in the Third world), Paris, La Découverte, 2004. 
(a) the multitude of other activities in which actors belonging to the informal sector engage as well - and which are systematically ignored, downplayed, or criticised. Indeed, resale, reuse, repair, refurbishment, repurposing, salvaging, etc. take place on a large scale in China. Not only do these practices cause little - if any - pollution, they also have the merit of extending product lifespan, thus limiting the need for raw materials to be extracted from the earth's crust or from scrap; ${ }^{(6)}$

(b) the environmental impact of large licensed plants' back-end treatment operations. Evidence from my research suggests pollution at this level easily goes unchecked, which tallies with a manifest dearth of reliable, comprehensive, or simply published data.

Second, the precise characteristics of the "management system" devised by central state authorities in order to determine the fate of discarded eappliances in China seem to be best explained by national policies that have little to do with environmental protection. I think here in particular of efforts to boost domestic consumption; to support the country's main manufacturers and retailers of electrical and electronic appliances; to better control the recycling industry and its profits; and to exhibit China's command of advanced, complex technologies as proof that it is - slowly but surely making its way into the select club of "developed countries" (fada guojia 发 达国家). Claims that state and industry are striving to minimise their environmental impact must be viewed in light of these priorities and with a good dose of scepticism toward green propaganda.

This study exposes the first results of my multi-sited ethnographic research on the fate of so-called "e-waste" (dianzi laji 电子垃圾) in China. Most of my fieldwork was done in the Pearl River Delta, where I spent a total of one year between 2014 and 2015, and in the Beijing-Tianjin area. I mainly "follow[ed] the thing," as George Marcus describes investigative methods that consist in tracking objects wherever they take centre stage. ${ }^{(7)}$ This led me to sites as different as repair shops, scrap yards, harbours, second-hand markets, conference halls, media websites, and legal texts. It also allowed me to meet the people who deal with discarded e-appliances - or the things from/into which they morph ${ }^{(8)}$ - on a daily basis and to get a sense of their actions and motivations. A total of 52 interviews were conducted with state officials, environmental activists, scientists, journalists, scrap dealers and recyclers, refurbishers and repairers, etc. Following Gille's advice, I investigated the ways in which so-called "e-waste" is not only treated, but also generated and portrayed, ${ }^{(9)}$ as these are all fundamental aspects of a waste regime.

This article is divided into four sections. The first one traces the social construction of "e-waste" as a public problem affecting China and exposes its influence on the quest for solutions. In the second section, I look at what happens to discarded e-appliances on the ground, identify key market players, describe their practices and technologies, and assess their respective strengths and weaknesses. The third section is devoted to attempts to transform this market and focuses on how green propaganda is mobilised by some as a tool to gain a competitive edge. In the fourth and final section, I suggest links between the evolution of China's e-waste regime and recent developments in different yet related fields.

\section{China: The world's e-waste dump}

The issue of discarded electrical and electronic appliances started to receive public attention throughout the world in the 2000s, due mainly to reports published by non-governmental organisations (NGOs) ${ }^{(10)}$ and the media, ${ }^{(11)}$ and quickly reached the status of global problem. (12) "E-waste," as it became known, was socially constructed (13) from the outset in terms of global injustice and environmental damage. To this day, the vast majority of accounts emphasise "illegal" exports from rich "developed" countries, which allegedly "dump" their waste onto poor, "developing" ones, and the pollution caused by small workshops in which this high tech equipment is dismantled and processed using "primitive" or "outdated" recycling technologies, such as open air burning and acid baths. ${ }^{(14)}$ In this narrative, China came to be known as the "world's largest e-waste dumpsite" (15) - an appellation that evokes, and contrasts with, its reputation as the "world's factory."

There is no reason to question the veracity of these accounts, or to downplay their role in raising awareness on the implications of mass consumption. At the same time, however, this framing of the "e-waste problem" has become a genre in itself that now tends to be taken for granted and reproduced unquestioningly.

It is significant that of all media and NGO reports, the one that arguably had the greatest impact ${ }^{(16)}$ dealt at length with the issue of discarded eappliances in China. This report focused the world's attention on Guiyu 贵 屿, a small town located in Guangdong Province that subsequently became e-waste's first poster child. It also inextricably tied the issue of discarded eappliances to images of migrant workers inhaling toxic fumes, of children playing barefoot on mountains of broken plastic cases, and of rivers turned black. In the years following this report's publication, Guiyu achieved infamy throughout China, especially when domestic media coverage described it as one of the country's most polluted places. ${ }^{(17)}$

Chinese scientists participated in drawing attention to the pollution caused by "primitive" recycling technologies. Scores of studies were pub-

6. Feng Wang et al., E-waste in China: A Country Report, op. cit., p. 17.

7. George E. Marcus, "Ethnography in/of the World System: The Emergence of Multi-Sited Ethnography," Annual Review of Anthropology, Vol. 24, 1995, pp. 95-117.

8. Josh Lepawsky and Charles Mather, "From Beginnings and Endings to Boundaries and Edges: Rethinking Circulation and Exchange Through Electronic Waste," Area, Vol. 43, No. 3, 2011, pp. 242-249.

9. Zsuzsa Gille, "Actor Networks, Modes of Production, and Waste Regimes: Reassembling the MacroSocial," art. cit., p. 1056.

10. See, e.g., Jim Puckett et al., Exporting Harm: The High-Tech Trashing of Asia, Basel Action Network \& Silicon Valley Toxics Coalition, 2002; Kevin Brigden et al., Recycling of Electronic Waste in China and India: Workplace \& Environmental Contamination, Amsterdam, Greenpeace International, 2005.

11. See, e.g., "The Electronic Wasteland," 60 Minutes, CBS News, 9 November 2008, available at www.cbsnews.com/video/watch/?id=4586903n (accessed in January 2015); "High-Tech Trash," National Geographic, January 2008, available at http://ngm.nationalgeographic.com/2008/01/ high-tech-trash/carroll-text (accessed in January 2015).

12. Tellingly, many international organisations now have programs on "e-waste."

13. Daniel Cefaï, "La construction des problèmes publics. Définitions de situations dans des arènes publiques" (The construction of public problems. Definition of situations in public arenas), Réseaux, Vol. 14, No. 75, 1996, pp. 43-66.

14. See, e.g., Madeleine Cobbing, Toxic Tech: Not in Our Backyard, Amsterdam, Greenpeace International, 2008.

15. Numerous articles came out in the Chinese press quoting a report by the United Nations University (Feng Wang et al., E-waste in China: A Country Report, op. cit.), which describes China as "the largest e-waste dumping site in the world." See, e.g.," Zhongguo huo shijie zuida dianzi laji chang, chanyelian lirun jingren" (China may be the largest e-waste dumping site in the world, supply chain's profits are astonishing), Zhongguo guangbo wang, 14 June 2013, available at http://china.cnr.cn/yxw/201306/t20130614_512816307.shtml (accessed in January 2015).

16. Jim Puckett et al., Exporting Harm: The High-Tech Trashing of Asia, op. cit.

17. Significantly, a Shanghainese television channel broadcasted footage of Guiyu on World Environment Day to illustrate the pollution problems faced by China: Guangdong Shantou Guiyu zhen dianzi laji wuran diaocha: jiucheng ertong zhongjinshu chaobiao, tizhi ruo yi huanbing (Survey of e-waste pollution in Guiyu Town: $90 \%$ of children beyond heavy metal limits, their constitution is weak and they fall ill easily), Shanghai Zaochen (Good Morning Shanghai), 5 June 2014, available at http://V.youku.com/v_show/id_XNTY2NjE2Mzky.html (accessed in January 2015). See also Anna Lora-Wainwright, "The Trouble of Connection: E-Waste in China Between State Regulation, Development Regimes and Global Capitalism," in I. Vaccaro et al., The Anthropology of Postindustrialism: Ethnographies of Disconnection, Oxford, Routledge (in press). 
lished in the field of toxicology on, for instance, lead levels in children's blood ${ }^{(18)}$ or human DNA damage, ${ }^{(19)}$ with the aim of quantifying the repercussions of these activities and proving their harmful nature. ${ }^{(20)}$ In general, results are conclusive.

The scientific community in China also played, and continues to play, an important role in the conception and handling of used e-appliances as a form of waste. The discourse on "e-waste" or "waste electrical and electronic equipment" (WEEE), (21) which now dominates in academic and policy-making circles around the world, implies that solutions are to be sought in the field of "waste management" (feiwu guanli 废物管理). In China, research on discarded e-appliances therefore focuses on material recovery and pollution control, (22) and is mostly conducted by specialists of environmental sciences.

\section{The shredder ideology and its corollaries}

Institutional experts' approach denotes an understanding of recycling as "resource recovery" (zaisheng ziyuan 再生资源 or ziyuanhua 资源化), namely the transformation of manufactured objects (computers, telephones) "back" into the materials they are composed of: plastics, aluminium, copper, gold, etc. ${ }^{(23)}$ Discarded e-appliances are seen as having reached the end of their lives; they have no usefulness as appliances anymore, but may, and should, be resuscitated as "raw materials" (yuanliao 原料), a process that experts tellingly refer to as "urban mining" (chengshi kuangchan 城市 矿产). An American scientist I interviewed dubbed this the "shredder ideology" and claimed that it prevailed in governmental, industrial, and academic circles in China. He pointed out that crushing, sorting, and extracting appear to be the obvious way to deal with discarded electrical and electronic appliances, even though other methods exist, some of which are "much more eco-efficient."

E-appliances' environmental impact by far exceeds the sole issue of backend waste management. (24) However, other issues have received comparatively little attention from the Chinese scientific community thus far. Work addressing the impact of product design on the longevity and potential toxicity of discarded appliances is scarce - despite the fact that several Chinese regulations promote the principle of eco-design. (25) Likewise, investigations into practices of reuse, repair, and refurbishment are largely lacking, ${ }^{(26)}$ although these practices are widespread in China. When asked to explain this, an employee of the Chinese Academy of Sciences who works on "a very small project on reuse" told me it was hard to get public funding for this type of research. Finally, manufacturing processes, which are known to generate a considerable amount of hazardous by-products and to affect the environment and human health, (27) do not figure prominently in Chinese scientists' program on "e-waste."

As is often the case with issues of waste, the status of discarded appliances affects that of the people who handle them. In China, the latter suffer from a thoroughly negative image. Interestingly, whereas accounts from European and North American sources give Asian and African small-scale recyclers the role of victims, those produced within mainland China on places such as Guiyu or Taizhou (28) make these people appear as both victims and perpetrators. News articles, for instance, stress the illegal activities that local business people engage in, such as smuggling, corruption, and tax evasion. ${ }^{(29)}$ Academics and environmental activists described them to me as being unruly, ruthless, or greedy, too steeped in their traditions to change. Such prejudices reflect the fact that these people are widely held responsible for the negative impact of discarded e-appliances.
It must be noted that the prevalent negative attitude towards the socalled "informal" sector of recycling is seldom based on a comprehensive evaluation of its impact. The vast majority of scientific studies concern themselves with the shape, efficiency, and future evolution of the "formal system" (zhenggui zhidu 正规制度), which refers to national and international regulations and policies, as well as to technologies used, or likely to be used, by large recycling companies. Research on the multitude of entities that make up the so-called "informal" sector and the various ways in which they deal with discarded e-appliances is lacking. ${ }^{(30)}$

\section{Scaling up the industry}

To this day, the great majority of discarded e-appliances in China lands in the hands of economic actors that are small-scale, privately owned, and linked into vast networks. ${ }^{(31)}$ Historical reasons largely account for this. When China embarked on economic reforms in the late 1980s and 1990s, state actors progressively disengaged from a number of sectors and private actors took over. In the case of recycling (in general), the latter were mainly people originating from the countryside. ${ }^{(32)}$ For them, switching from farming to scrap collecting, dealing, dismantling, and/or processing was a way to improve their modest earnings. Some of them made a fortune, thanks to good commercial skills and, more importantly, favourable business conditions. The country's rapid growth, in particular in the areas of construction

18. Xia Huo et al., "Elevated Blood Lead Levels of Children in Guiyu, an Electronic Waste Recycling Town in China," Environmental Health Perspectives, Vol. 115, No. 7, 2007, pp. 1113-1117.

19. Qiang Liu et al., "Chromosomal Aberrations and DNA Damage in Human Populations Exposed to the Processing of Electronics Waste," Environmental Science and Pollution Research International, Vol. 16, No. 3, 2009, pp. 329-338

20. Janet Kit Yan Chan and Hung Wong Ming, "A Review of Environmental Fate, Body Burdens, and Human Health Risk Assessment of PCDD/Fs at Two Typical Electronic Waste Recycling Sites in China," Science of The Total Environment, Vol. 463-464, 2013, pp. 1111-1123.

21. This expression first appeared in the European Union's WEEE Directive (2002/96/EC). In China, official documents mention "discarded electrical and electronic products" (feiqi dianqi dianzi chanpin), but experts tend to refer to these objects as "e-waste" (dianzi feiqiwu or dianzi laji).

22. Yunxia He and Zhenming Xu, "The Status and Development of Treatment Techniques of Typical Waste Electrical and Electronic Equipment in China: A Review," Waste Management \& Research, Vol. 32, No. 4, 2014, pp. 254-269.

23. See, e.g., Wenzhi He et al., "WEEE Recovery Strategies and the WEEE Treatment Status in China," Journal of Hazardous Materials, Vol. 136, No. 3, 2006, pp. 502-512.

24. Fabrice Flipo et al., La face cachée du numérique (The hidden side of electronics), Montreuil, L'échappée, 2014.

25. Martin Streicher-Porte et al., "Chinese E-Waste Legislation, Current Status and Future Development," ELNI Review, Vol. 1, 2010, pp. 7-17.

26. For an exception, see Bin Lü and colleagues: Lü Bin and Yang Jianxin, "Zhongguo dianzi feiqiwu huishou chuli tixi de shengtai xiaolü fenxi" (An analysis of the ecological efficiency of China's ewaste treatment system), Huanjing gongcheng xuebao, Vol. 4, No. 1, 2010, pp. 183-188; Bin Lü et al., "Reusability Based on Life Cycle Sustainability Assessment: Case Study on WEEE," Proceedings of the 21st CIRP Conference on Life Cycle Engineering, 2014, pp. 473-478.

27. Ted Smith et al. (eds), Challenging the Chip: Labor Rights and Environmental Justice in the Global Electronics Industry, Philadelphia, Temple University Press, 2006.

28. Taizhou is another well-known processing hub located in Zhejiang Province.

29. See, e.g., "Shantou Guiyu dianzi laji chanyelian: tilian de tong bei zousi chuqu zao zidan" (E-waste supply chain in Guiyu, extracted copper smuggled to make bullets), Huanqiu chaoren, 4 July 2014, available at http://news.hqcr.com/projects/news/view.aspx?nid=420326 (accessed on January 2015).

30. Xinwen Chi et al., "Informal Electronic Waste Recycling: A Sector Review with Special Focus on China," Waste Management, Vol. 31, No. 4, 2011, p. 735. For an exception, however, see Xian Li et al., "Informal WEEE Recycling in China: A Field Study of Stakeholders in Tianjin," International Journal of Environmental Science and Development, Vol. 3, No. 5, 2012, pp. 422-426.

31. Xinwen Chi et al., "Informal Electronic Waste Recycling: A Sector Review with Special Focus on China," art. cit., p. 732; Feng Wang et al., E-waste in China: A Country Report, op. cit., p. 17.

32. Adam Minter, Junkyard Planet: Travels in the Billion-Dollar Trash Trade, London, Bloomsbury Press, 2013; Devona Ensmenger et al., "Talking Trash: An Examination of Recycling and Solid Waste Management Policies, Economies, and Practices in Beijing," East West Connections, Vol. 5, No. 1, 2005, pp. $190 \mathrm{ff}$ 
and manufacturing, required huge quantities of raw materials, and dealers in "secondary resources" were in a position to supply China's factories generally by importing scrap from overseas. (33) Discarded e-appliances served as a source of not only plastics and metals, but also of cheap components with which devices could be repaired or refurbished, ${ }^{(34)}$ or as affordable second-hand consumer goods.

The sector of "e-waste" recycling was long characterised by a near absence of state intervention. But this situation has changed in recent years, and the central government now seeks to control it. Although the first attempts at regulating the trade date back to the early 2000s, it was not until the early 2010s that tangible results were achieved: the central government succeeded in triggering the emergence of new players in the field, namely large scrap processing companies (chuli qiye 处理企业). The policies and regulations currently in place are exclusively oriented toward the latter, shaped in ways consistent with their needs and capabilities and aimed at promoting their interests. They require centralised operations, vast facilities, state-of-the-art industrial equipment, automated processes, comprehensive information management systems, and most importantly, an exclusive focus on material recovery. This makes compliance all but impossible for the majority of actors who currently control flows of discarded e-appliances in China, and therefore excludes them from the country's "formal system of WEEE management." (35)

In public statements, experts claim that it is necessary to "increase the scale" of the industry (chanye guimohua 产业规模化), which clearly translates into prioritising and promoting big companies. They talk of "standardising" or "normalising" the industry (chanye guifanhua 产业规范化 or zhengguihua 正规化), or in other words of increasing the level of conformity with rules and regulations. Since the Chinese WEEE Directive and related legal texts are not designed to accommodate self-employed workers, individual entrepreneurs, and privately owned small enterprises (getihu 个体户 or sanhu 散户), (36) this implies doing away with these actors. Attempts to scale up the industry are an important element in the current waste regime's transformation.

Getting rid of "dismantling workshops" (chaijie zuofang 拆解作坊), for instance, is a deliberate objective for government agencies. A high-ranking official of China's Ministry of Environmental Protection (MEP) explained to me: "We are cracking down on them and using economic methods to promote their competitors. The more big recycling plants there are, the harder it will be for small workshops to survive." The official also acknowledged that "crackdowns are not particularly effective, since workshops often reopen or relocate soon after they are closed down, but we believe economic methods can achieve good results." "Economic methods" basically consist in subsidies (butie 补贴) allocated to state-registered, licensed companies. The central government introduced them in two phases. In the first one, it sought to kick-start the "formal" recycling sector by launching a take-back program called "Home Appliance Old-for-New Rebate Program" (jiadian yi jiu huan xin zhengce 家电以旧换新政策). ${ }^{(37)}$ This program ran from 2009 to 2011 and was fully financed with state funds. It encouraged consumers all over China to sell their unwanted devices exclusively to registered and authorised collectors in order to receive a discount on the purchase of new ones in large retail stores such as Gome (Guomei 国美) and Suning 苏宁. The program was quite effective in supplying "e-waste" to new recycling plants, which were securing very little at the time, but it proved too expensive for the government, and collection rates dropped as soon as it ended. In a second phase, which has lasted until today, the central government shifted the financial burden onto producers (shengchanzhe 生产者, i.e. manufacturers and importers) by making it mandatory to pay a tax on each appliance put on the Chinese market. The money thus collected goes into a state-managed fund (jijin 基金) and is then redistributed to recyclers, who receive a fixed amount per processed "item" (i.e. full appliance). The whole purpose of the subsidy is to give licensed recyclers a comparative advantage on the market and make them competitive. At the end of 2014, more than 100 companies were receiving financial support in the form of subsidies. All of them depend on it for their survival. In fact, some plants even interrupted or slowed down their lines in 2015 due to delayed payments from the government. In major cities, one generally finds at least one recycling company with strong ties to state authorities.

The central government is more tolerant towards small actors involved in the collection of discarded e-appliances, at least for now. In China, most unwanted objects (old television sets, worn-out clothes, cardboard boxes, etc.) are gathered, sorted, and pre-processed by "rubbish collectors" (called shou polan de ren 收破烂的人 or, euphemistically, xiaoshangfan 小商贩), and then sold to specialised "privately-owned scrap stations" (siying feipinzhan 私营废品站) or "small scrapyards" (xiao huochang 小货场). The people running these businesses are often members of China's "floating population" (liudong renkou 流动人口). They operate with great economic efficiency, cutting down on all costs (transportation, labour, equipment, etc.), and they control the "last mile," a key feature according to experts in reverse logistics. In other words, they are in immediate contact with the source of discarded e-appliances and therefore play a crucial role in the supply chain.

In today's China, doing without them would be tricky. Local authorities largely rely on them for the management of municipal solid waste. For instance, Guangzhou's city management (chengguan 城管) urges residents to "go and sell what can be sold" (neng mai na qu mai 能卖拿去卖), which, in the absence of true alternatives, amounts to (tacitly) endorsing rubbish collectors. State-registered recyclers also depend on the latter for their supply of discarded e-appliances. They are allowed to source from these people, for the system is currently based on the principle of "multichannel collection" (duoqudao huishou 多渠道回收). But this may change in the future, since government and academic experts call for an "integration" (yitihua 一体化) of the collection network. Although they rarely give details on the implementation of this process, experiments currently being conducted throughout China ${ }^{(38)}$ indicate that self-employed migrant workers would be left with, at best, a minor role to play. ${ }^{(39)}$

In general, the progressive waning of the "informal" sector of "e-waste" recycling is largely regarded by scientists, environmentalists, and corporate or government representatives as an ineluctable and, on the whole, desirable evolution. Those I interviewed think that, in time, not only polluting work-

33. Xin Tong and jinci Wang, "The Shadow of the Global Network: E-Waste Flows to China," in Catherine Alexander and Joshua Reno (eds), Economies of Recycling: The Global Transformations of Materials, Values and Social Relations, London, Zed Books, 2012, pp. 98-116.

34. Adam Minter, Junkyard Planet: Travels in the Billion-Dollar Trash Trade, op. cit., p. 199.

35. See also Anna Lora-Wainwright, "The Trouble of Connection: E-Waste in China Between State Regulation, Development Regimes and Global Capitalism," art. cit.

36. Xinwen Chi et al., "Informal Electronic Waste Recycling: A Sector Review with Special Focus on China," art. cit., p. 735.

37. See Feng Wang et al., E-waste in China: A Country Report, op. cit., p. 34.

38. E.g., take-back through large retail chain stores, home pick-up organised by licensed recyclers, deposit in hermetic and automatic boxes located in residential areas.

39. See also Devona Ensmenger et al., "Talking Trash: An Examination of Recycling and Solid Waste Management Policies, Economies, and Practices in Beijing," art. cit., p 122. 
shops will vanish, but also self-employed rubbish collectors, privately-owned scrap stations, family-operated scrapyards, etc. In specialised conferences, the "informal" sector is rarely mentioned, or only in passing and in thoroughly negative terms. Several of my non-Chinese informants even reported that when they tried to discuss the issue with their Chinese counterparts, they were told, "There is no informal sector in China." Such a forthright denial may be uncommon, but it is symptomatic of a widespread inability to acknowledge the role and importance of these people. ${ }^{(40)}$

Guiyu's industrial park represents an interesting case in point because it reveals how long and bumpy the "formalisation" road can be. In 2005, the central government declared Guiyu the country's first "circular economy experimentation point" (xunhuan jingji shidian 循环经济试点). Five years later, the government of Guangdong Province made the construction of a "demonstration park" for "comprehensive recycling" (zonghe liyong chanye shifanyuan 综合利用产业示范园) one of its priority programs. A vast stretch of land was therefore made available for the construction of what was to become a flagship industrial park. For years, however, the park remained almost empty; Guiyu's recyclers refused to move in. Only recently have some started to do so - after having received threats from the neighbouring city's Environmental Protection Bureau. But the type of operations conducted in the park today are not the most problematic ones, and the methods used there do not fundamentally differ from those encountered outside. In other words, the result remains a far cry from expectations.

The recent crackdown on small workshops in the town of Longtang (Longtang zhen 龙塘镇), another well-known processing hub located in Guangdong Province that has been active for years, also reveals that local governments benefit from the trade in terms of revenue and only intervene when ordered to do so by higher authorities.

\section{Primacy thanks to a diversified strategy}

When considered at all, small economic actors are portrayed as the source of an unfair competition that allegedly diverts goods away from the "formal" sector. (41) Indeed, despite the financial support "formal companies" (zhenggui qiye 正规企业) receive from the central government, they have only been processing relatively small quantities of used e-appliances thus $\mathrm{far}^{\left({ }^{(42)}\right)}$ at least compared with the total volume generated each year in China. Experts tend to blame this shortage of goods on the "informal" sector, arguing that small, independent economic actors manage to offer higher prices than state-registered companies because, unlike them, they are not compelled to comply with regulations. This allows them to save on a wide range of costs, especially those related to pollution control, (43) which are said to be especially high. Such statements are true, but also simplistic. Getting away with polluting can help enhance one's profit - as the literature on "pollution havens" (44) demonstrates - yet it hardly represents a business model in itself.

My fieldwork suggests that small and independent economic actors' competitive advantage results less from their disrespect for the law than from the fact that they can choose from a vast array of practices, some of which fall within the scope of the law whereas others do not. Big, licensed Chinese "e-waste" recycling companies operating in China do not have such an option. They calculate purchasing prices based on two factors: the subsidy they can claim from the government and the selling prices of materials (metals, plastics) on commodity markets. Since the subsidy is awarded for the destruction - officially termed "treatment" (chuli 处理) - of e-appliances, li- censed companies are strongly incentivised to drop these objects in shredders. It is the production of fractions (bits and pieces, powders, etc.) that creates economic value. In contrast, small and independent actors - when considered collectively - enjoy greater leeway and adopt a more diversified strategy. Indeed, they tend to (in sequential order): reuse devices, repair them, salvage components, and extract materials. ${ }^{(45)}$ Material recovery, for them, is only one option among others, not a necessity. Of course, appliances that are broken beyond repair or outdated beyond resale serve only as a source of materials. But if a device or component is still functional, or in a good enough condition to make repair worthwhile, chances are that it will be reused. (46) The neighbourhood repair shops (jiadian weixiu dian 家电 维修店) and markets for second-hand electronics (dianzi ershou shichang 电子二手市场 or dianzi cheng 电子城) that can be found everywhere in China testify to this reality. Adam Minter even reports being told that, in the recent past, business people in Guiyu and Taizhou made $80 \%$ of their profit thanks to reuse. ${ }^{(47)}$ This is not hard to understand. Functionality gives manufactured products an added value compared to "raw" materials. By preserving it, one can reap benefits, make more profit and, in turn, offer higher purchasing prices. ${ }^{(48)}$ This is the driving principle behind Guangdong's huge and lively markets for refurbished high-end smartphones and liquid crystal displays. In sum, if "informal" actors prove to be more competitive than "formal" ones, it is also because they are more flexible and manage to realise more fully the market potential of each appliance. Here, so-called "unfair" competition is actually backed by good business acumen.

Cathode-ray tube (CRT) television sets (TVS) are a good illustration of how competition works out with regard to discarded e-appliances. TVs in China have several important characteristics that distinguish them from other types of appliance. First, they became common among the population in the 1980s, at a time when refrigerators and washing machines were still a luxury - not to mention air conditioners and computers. Compared to these devices, CRT TVs have had a longer time to accumulate in households, hotels, etc. Old TVs are therefore particularly widespread. Second, television technology has recently gone through nothing short of a revolution. New wide-screen devices equipped with a flat panel display (FPD) are light and easy to carry, whereas, a few years back, CRT TVs of equivalent screen sizes were extremely cumbersome. Third, the prices of FPDTVs have dropped significantly in recent years, so that most people can afford to buy one nowa-

40. See also Anna Lora-Wainwright, "The Trouble of Connection: E-Waste in China Between State Regulation, Development Regimes and Global Capitalism," art. cit.

41. See, e.g. Xin Tong and jinci Wang, "The Shadow of the Global Network: E-Waste Flows to China," art. cit., p. 113.

42. Xinwen Chi et al., "E-Waste Collection Channels and Household Recycling Behaviors in Taizhou of China," Journal of Cleaner Production, Vol. 80, 2014, pp. 87-95.

43. Xinwen Chi et al., "Informal Electronic Waste Recycling: A Sector Review with Special Focus on China," art. cit., p. 735.

44. See, e.g., Jennifer Clapp, Toxic Exports: The Transfer of Hazardous Wastes from Rich to Poor Countries, Ithaca, Cornell University Press, 2001.

45. Martin Streicher-Porte and Anne-Catherine Geering, "Opportunities and Threats of Current EWaste Collection System in China: A Case Study from Taizhou with a Focus on Refrigerators, Washing Machines, and Televisions," Environmental Engineering Science, Vol. 27, No. 1, 2010, pp. 29-36; Xinwen Chi et al., "Informal Electronic Waste Recycling: A Sector Review with Special Focus on China," art. cit:; Adam Minter, Junkyard Planet: Travels in the Billion-Dollar Trash Trade, op. cit., p. 105.

46. Jianxin Yang et al., "WEEE Flow and Mitigating Measures in China," Waste Management, Vol. 28, No. 9, 2008, p. 1592

47. Adam Minter, Junkyard Planet: Travels in the Billion-Dollar Trash Trade, op. cit., p. 107 and p. 196.

48. See Jianxin Yang et al., "WEEE Flow and Mitigating Measures in China," art. cit., and Xinwen Chi et al., "Informal Electronic Waste Recycling: A Sector Review with Special Focus on China," art. cit., p. 733 . 
days, at least in cities. As a result, the reuse market for old, bulky CRT TVs has shrunk and continues to do so. In addition, the materials CRT TVs are made of have little economic value. They include a lot of heavy leaded glass (unmarketable), some plastics (low value), and only a little copper (high value). Because of all these characteristics, CRT TVs are relatively unattractive for business purposes. ${ }^{(49)}$ Large-scale "formal" recyclers in China thus face less competition and secure them more easily than other devices, such as refrigerators, air conditioners, and washing machines not to mention computers and FPD TVs. Indeed, official figures indicate that more than $80 \%$ of their total supply, on average, consists of CRT TVs. ${ }^{(50)}$ Admittedly, other factors also account for this product distribution - for example, the fact that the subsidy for TVs is relatively high (85 yuan/unit) - but none of them plays as decisive a role as the low reuse value of this type of e-appliance. The situation is entirely different if we look at air conditioners or computers, for instance. One can easily find second-hand markets in China that sell these types of appliances by the thousands.

Thus, the fate of appliances, and the question of whose hands they eventually end up in, is largely determined by how much value can be drawn out of them and how. A waste regime that fails to integrate this can only be made effective through repressive measures. It may push parallel markets underground, but is unlikely to eliminate them. ${ }^{(51)}$

\section{Mobilising greenness}

The transformation of China's waste regime requires an important effort on symbols and words. "Formal" actors dealing with used e-appliances not only routinely accuse "informal" ones of unfair competition and environmental damage, but also mobilise green propaganda as an instrument to demarcate themselves from their competitors and gain a competitive edge.

Academic experts, government officials, and representatives of big recycling companies make great efforts to present China's "formal system of WEEE management" as the only viable solution for dealing with flows of "e-waste" in a clean manner and, in doing so they draw heavily on ecological ideology and iconography. The colour green, images of pristine natural landscapes, diagrams showing hermetic material loops and cycles, and concepts such as the "circular economy" (xunhuan jingji 循环经济) and "ecological civilisation" (shengtai wenming生态文明) abound in corporate promotional flyers and websites, academic publications, government policy papers, and media reports. Significantly, big recycling companies are now commonly referred to in China as "environmental protection companies" (huanbao gongsi 环保公司) - as if their business consisted not so much in making a profit by breaking objects, separating materials, and selling them, as in ensuring the cleanliness of China's air, ground, and water. Their contribution to the safety and well-being of the population is sometimes stressed and praised to such an extent that one almost forgets their fundamental nature as for-profit ventures. This profusion of green propaganda serves the purpose of making the proponents of China's "formal system" appear as the only legitimate actors of "e-waste management."

But state-registered recycling companies are not nearly as green as they claim to be. When digging through the crust of propaganda, one encounters several inconsistencies. Firstly, as mentioned already, these companies systematically destroy objects, regardless of their reuse potential. ${ }^{(52)}$ This clearly contravenes the principle of "waste hierarchy" (also known as the "doctrine of the 3Rs"), which stipulates that recycling should take place only as a last resort, after attempts have been made, first, to reduce consumption, and second, to reuse objects. International experts in environmental sciences acknowledge that reuse should also be privileged in the case of "e-waste." (53) Secondly, big recycling companies in China face the same hurdles as everyone else in dealing with materials that have little or no commercial value. Most of them send leaded glass from CRT TVs to landfills or incinerators, for instance, because too few applications - and therefore business opportunities - are available nowadays for this material. ${ }^{(54)}$ Considering that a single CRT tube includes up to two kilograms of lead, this amounts to millions of tons of highly toxic material that end up unrecycled every year. Landfilling and incineration may be preferable to dumping, provided they respect certain standards, but these techniques do not quite qualify as "green," and certainly not as "circular." Thirdly, despite the MEP's allegedly "stringent requirements and controls," many "formal" recyclers still lack the complex depollution equipment required to ensure a neutral impact on the environment. ${ }^{(55)}$

More generally, green propaganda should not make us oblivious to the fact that transforming matter is never an entirely clean process. To be sure, recycling old appliances is preferable to casting them aside and letting them disintegrate. In some cases, using complex technologies and heavy industrial equipment is necessary to thoroughly extract, segregate, purify, and stabilise materials. ${ }^{(56)}$ At the same time, however, breaking objects into pieces is like opening Pandora's Box: it unleashes substances that are hard to control afterwards. ${ }^{(57)} \mathrm{A}$ myriad of precautions must be taken in order to avoid unwanted consequences (i.e. contamination). No one can take them all, of course, and there is ample evidence that licensed recycling plants in China could do more in this field. Thus, claims of total greenness on the part of proponents of the "formal system of e-waste management" should be taken with a grain of salt.

Finally, it is crucial to stress that these claims originate in distorted comparisons between the "informal" and "formal" sectors. Dominant representations in favour of the latter are persuasive in large part because they rely on a narrow perspective centred on material recovery. If other methods of dealing with discarded e-appliances were factored into the analysis, the "informal" sector would not look as bad as it currently does. Indeed, small eco-

49. See also Josh Lepawsky and Charles Mather, "A Terminal Condition:The Cathode Ray Tube's Strange Afterlife," The Atlantic, April 2014.

50. See, e.g., Qingbin Song et al., "The Life Cycle Assessment of an E-Waste Treatment Enterprise in China," Journal of Material Cycles and Waste Management, Vol. 15, No. 4, 2013, pp. 469-475. My personal observations in recycling plants tally with the proportions mentioned above.

51. See Yvan Schulz, "Fin de vie et renaissance clandestine. Le sort des écrans plats en Chine du Sud" (End of life and clandestine rebirth. The fate of flat screens in South China), Techniques \& Culture (forthcoming).

52. Some companies claim that they sell functional devices (those for which no subsidy can be obtained from the government) on second-hand markets, but this seems to be a marginal practice.

53. StEP (Solving the E-waste Problem), One Global Understanding of Re-Use-Common Definitions, Bonn, StEP, 2009.

54. Qingbin Song et al., "Life Cycle Assessment of TV Sets in China: A Case Study of the Impacts of CRT Monitors," Waste Management, Vol. 32, No. 10, 2012, pp. 1926-1936; Qingbo Xu et al.," "Cathode Ray Tube (CRT) Recycling: Current Capabilities in China and Research Progress," Waste Management, Vol. 32, No. 8, 2012, pp. 1566-1574. Qingbin Song et al. write that CRT panel glass is incinerated while CRT funnel glass is reused in the production of new CRT displays. But, as Qingbo $\mathrm{Xu}$ et al. acknowledge, there is almost no demand for this material nowadays, since very few CRTs are manufactured anymore.

55. Feng Wang et al., E-waste in China: A Country Report, op. cit., p. 26

56. United Nations Environment Program (UNEP), E-Waste Volume II: E-Waste Management Manual, Osaka/Shiga, UNEP, 2007.

57. Catherine Alexander and Joshua Reno, "Introduction," in Catherine Alexander and Joshua Reno (eds), Economies of Recycling: The Global Transformations of Materials, Values and Social Relations, London, Zed Books, 2012, pp. 1-32. 
nomic actors engage in practices of reuse and repair on a large scale in China - whereas, in general, large ones do not. ${ }^{(58)}$ By doing so, they extend the lifespan of huge amounts of discarded e-appliances and therefore prevent these consumer goods from becoming "e-waste" to begin with. This makes "e-waste management" and the production of new (replacement) devices superfluous. ${ }^{(59)}$ Therefore, many small economic actors actually contribute to reducing the overall environmental impact of discarded e-appliances. In principle, this should be acknowledged, even praised, in public discourse. Yet, it is systematically ignored or downplayed in the face of a dominant discourse on pollution.

\section{Materials, modernity, and mass consumption}

Why is China's "formal system of e-waste management" centred on industrial-scale material recovery? In order to answer this question we must look at where the people who devised it drew their inspiration. From the outset, China's national policies and regulations on "e-waste" were modelled on those found in highly industrialised regions of the world, ${ }^{(60)}$ where material recovery has imposed itself as the preferred method for dealing with discarded e-appliances. The main Chinese laws on "e-waste," for instance, draw on the European Union's WEEE Directive, which was the first text to regulate the issue of discarded e-appliances in a comprehensive way. To this day, Chinese scientists and policy-makers continue to monitor and imitate developments taking place "abroad" (guowai 国外) - which invariably means in countries with a high level of industrialisation. In conference talks, these people systematically mention "developed" countries as a source of inspiration. Likewise, paragraphs and chapters on "the status quo of WEEE recycling in the United States" or "the latest situation in Japan" abound in the Chinese scientific literature. ${ }^{(61)}$ Comparing China with these countries seems like a standard thing to do. Scientific and government experts do not regard developments there solely as a source of new ideas; they wish to emulate them. ${ }^{\left({ }^{2} 2\right)}$ Again and again, I heard them say: "We still have a long way to go until we can [adopt the same regulations/enforce the same standards/use the same machines/etc.] as [Germany/Korea/Taiwan/Great Britain/etc.], but we will get there eventually." (63)

With such a mindset, Chinese experts take for granted that exclusive industrial-scale material recovery is the best way of dealing with discarded e-appliances. The question of whether or not this method is appropriate to the current situation in China becomes largely irrelevant. As a matter of fact, some of the solutions favoured by Chinese policy-makers and their advisors are not in line with existing needs and capabilities within the country. An environmental engineer I interviewed told me, for instance, that in the relatively near future, "the [Chinese] central government wants to have high-tech specialised smelters, like those owned by Umicore [a multinational company with headquarters in Belgium], although they cost hundreds of millions of U.S. dollars and need to be fed with a lot of stuff, which China doesn't manage to collect through formal channels at the moment." The idea that other methods and technologies than those used by developed countries may be more appropriate is thus ruled out.

The symbolic dimension of technologies also plays an important role. Whether or not they are deemed attractive depends not only on the achievements they enable, but also on what they stand for in the minds of people, as the field of science-technology-society studies has amply demonstrated. (64) Material recovery, as it is practiced in "developed" countries, has an aura of scientificity and innovation. It requires sophisticated equipment, automated processes, expensive investments, abundant information, elaborate laws, etc. - things that all evoke technological progress and modernity. Among the various methods used to deal with discarded eappliances, it is certainly the one that fits best with China's "medium- to long-term plan" to become a world leader in science and technology by 2050. ${ }^{(65)}$ Together with space programs and mega-projects in civil engineering, industrial-scale material recovery serves as a token of the country's modernity.

Material recovery's success is also due to another of its characteristics: it is compatible with increased consumption and production rates, unlike other ways of drawing value out of discarded e-appliances. The more appliances are bought, used, and discarded, the more business for recyclers. Conversely, the more appliances are crushed and transformed back into their basic constituents, the more raw materials manufacturers have at their disposal to produce new stuff. Whereas repair and reuse are likely to impinge on sales of new devices, harm manufacturers' interests, and slow down the growth of the national electronics industry, material recovery serves the interests of the manufacturing industry by making secondary raw materials available sooner and in larger quantities. It is no coincidence that "formal" collection schemes for old devices in China are often coupled with measures aimed at increasing sales of new ones. The "Old-for-New" take-back scheme, for instance, was designed not only to redirect "e-waste" from the "informal" to the "formal" sector, but also to boost domestic consumption in the face of a worldwide economic slowdown and a weakened demand for manufactured goods in China's export markets. ${ }^{(66)}$ Similarly, some "formal" recyclers buy back devices from consumers with credit - not cash that can only be used to purchase new consumers goods. ${ }^{(67)}$

On the whole, producers approve of China's "formal management system" for discarded e-appliances. The fact that it is based exclusively on industrial-scale material recovery is in line with their fundamental interests, i.e., to sell a maximum quantity of goods. If large recycling plants were to wrest discarded e-appliances entirely from the "informal" sector, reuse practices

58. Though Apple and Foxconn's 2015 iPhone take-back, refurbishment, and resale program may have set a precedent. See James Griffiths and Wu Nan, "Apple launches iPad and iPhone trade-in scheme across Greater China," SCMP, 31 March 2015, available at www.scmp.com/lifestyle/ technology/enterprises/article/1752436/apple-launches-ipad-and-iphone-trade-scheme-china (accessed in April 2015).

59. See Walter R. Stahel, "The Product-Life Factor," in Susan Grinton Orr (ed.), An Enquiry into the Nature of Sustainable Societies: The Role of the Private Sector, Houston, Area Research Center, 1982, pp. 72-96.

60. Xin Tong and Lin Yan, "From Legal Transplants to Sustainable Transition: Extended Producer Responsibility in Chinese Waste Electrical and Electronic Equipment Management," Journal of Industrial Ecology, Vol. 17, No. 2, 2013, p. 200.

61. See, e.g., Li Jinhui et al. (eds), Feiqi dianqi dianzi chanpin guanli zhengce yanjiu (Research on Policies for the Management of Discarded Electrical and Electronic Products), Beijing, Zhongguo huanjing chubanshe, 2011.

62. See, e.g., Wenzhi He et al., "WEEE Recovery Strategies and the WEEE Treatment Status in China," art. cit.

63. See also Xin Tong and Lin Yan, "From Legal Transplants to Sustainable Transition: Extended Producer Responsibility in Chinese Waste Electrical and Electronic Equipment Management," art. cit., p. 200.

64. Stephen H. Cutcliffe, Ideas, Machines, and Values: An Introduction to Science, Technology, and Society Studies, Oxford, Rowman \& Littlefield, 2000.

65. Cong Cao et al., "China's 15-Year Science and Technology Plan," Physics Today, Vol. 59, No. 12, 2006, pp. 38-43.

66. Xin Tong and Lin Yan, "From Legal Transplants to Sustainable Transition: Extended Producer Responsibility in Chinese Waste Electrical and Electronic Equipment Management," art. cit., p. 206; Feng Wang et al., E-waste in China: A Country Report, op. cit., p. 38.

67. See, e.g., "Zaisheng ziyuan gonggong fuwu pingtai, Shanghai Jinqiao zaisheng ziyuan shichang" (Recyclable resource public service platform, Shanghai Jinqiao Recyclable Resource Transaction Market), www.alahb.com (accessed in January 2015). 
would vanish, or at least decrease drastically, and buying new devices would become the only option left for consumers. At present, producers have to pay a recycling tax on every e-appliance they put on the Chinese market, but this has not triggered much opposition, for several reasons. First, the tax has been set at a maximum of 13 yuan per item, ${ }^{(68)}$ which accounts for a small portion of the total price in most product categories. Second, producers are encouraged by law to build their own recycling plants. ${ }^{(69)}$ Several major groups, among them TCL (TCL Jituan gufen youxian gongsi TCL 集团 股份有限公司) and Changhong (Sichuan Changhong dianzi jituan youxian gongsi 四川长虹电子集团有限公司), took advantage of this option. It allows them to recoup part of the expenditure: the manufacturing branch pays a recycling tax, but the recycling branch receives some of this money back in the form of subsidies. Even producers whose goods currently fail to appear in "formal" recyclers' shredders - e.g., air conditioners, printers, and mobile phones - voice remarkably little discontent. A corporate representative working for a multinational corporation, for instance, complained in private about the lack of transparency in China's tax system and made no secret of her efforts to convince central government agencies to give producers more leeway. But she did not fundamentally question the mechanism.

In sum, the waste regime currently being promoted at the institutional level in China has clear connections with other state policies. It is congruent with national plans for the development of science and technology, consonant with the growing emphasis on ecological modernisation (70) and techno-nationalism, ${ }^{711}$ and compatible with higher production and consumption rates, on which China relies for the development of its manufacturing industry as well as, more generally, for its economic growth.

\section{Conclusion}

In this paper, I argued that the path on which China has embarked in order to solve its "e-waste problem" may well limit, or even eliminate, pollution caused by certain forms of recycling, but certainly will not improve e-appliances' overall environmental impact. The benefit of a more effective and cleaner "waste management," supposedly brought about by the country's new "formal system," is offset by this system's requirement that devices be systematically destroyed, for this accelerates waste generation. In this sense, the discourse of environmental protection, which serves to justify restructuring the "e-waste" recycling sector, should not be taken at face value. Above all, it is an asset that certain actors mobilise - alongside scientific and media authority, state power, corporate funding, etc. - to advance their own interests. By nurturing preconceptions of who is green and who is not, large industrial groups seek to transform the market for used e-appliances and gain an edge in the competition for access to valuable objects and strategic materials. They enjoy support from the Chinese central government, research institutes, and the media, who share a common definition of recycling as the destruction of consumer goods and the creation of raw materials.

Supplanting the actors who currently control the trade and transformation of discarded e-appliances in China promises to be a difficult task. They have accumulated experience over decades, are networked in intricate ways both among themselves and with local political authorities, and most importantly, enjoy considerable freedom in the organisation of their business activities. Their quest for profit shows that there are different ways of dealing with discarded e-appliances and that the exclusive use of material recovery is not only environmentally undesirable, but also economically unviable.

Using "e-waste" recycling as an entry point, this article described attempts to put into practice the principle of a "circular economy." We have seen that concretely, implementing measures actually bolster larger and faster material cycles. China's goal of "ecological modernisation" implies transforming its waste regime to make it more resource-intensive and therefore more wasteful. No amount of green varnish will hide the fact that a holistic and truly responsible approach to e-appliance's overall environmental impact is lacking in China - as is the case elsewhere in the world, unfortunately. Viewed in this light, optimistic takes on the emergence of a "green state," (72) or "green capitalism," (73) and on China's privileged role as an incubator thereof, take on a disquieting hollowness.

I Yvan Schulz is a PhD candidate at the Anthropology Institute, University of Neuchâtel, and an associate researcher at the School of Philanthropy, Sun Yat-sen University.

Anthropology Institute, University of Neuchâtel, Saint-Nicholas 4, 2000 Neuchâtel, Switzerland (yvan.schulz@unine.ch).

68. See "'Dianzi laji' chuli jijin 7 yue kaizheng" ("E-waste" treatment fund will begin to be taxed in July), Hexun wang, 1 June 2012, available at http://funds.hexun.com/2012-0601/141997667.html (accessed in January 2015).

69. Xin Tong and Lin Yan, "From Legal Transplants to Sustainable Transition: Extended Producer Responsibility in Chinese Waste Electrical and Electronic Equipment Management," art. cit., p. 200.

70. Arthur P. J. Mol, "Environment and Modernity in Transitional China: Frontiers of Ecological Modernization," Development and Change, Vol. 37, No. 1, 2006, pp. 29-56.

71. Andrey B. Kennedy, "China's Search for Renewable Energy: Pragmatic Techno-Nationalism," Asian Survey, Vol. 53, No. 5, 2013, pp. 909-930.

72. Robyn Eckersley, The Green State: Rethinking Democracy and Sovereignty, Cambridge, The MIT Press, 2004.

73. John Mathews, Greening of Capitalism: How Asia Is Driving the Next Great Transformation, Stanford, Stanford University Press, 2014. 